\title{
Baltimore's Slum Housing Clinic
}

\author{
ROBERT F. SWEENEY, LL.B.
}

$\mathrm{T}$ HE BLIGHT of slums that faces Baltimore is not unique; the same civic cancer troubles most of the large cities in the United States today. Some original techniques have been devised by Baltimoreans to combat slums, however, and several have been copied by similarly affected cities. Among these is the socalled Baltimore plan, an effort to bring about block-by-block rehabilitation, structurally and aesthetically, through the cooperation of property owners, occupants, police department, and the Baltimore Bureau of Urban Renewal and Housing Authority. Baltimore also pioneered in code enforcement with the creation in 1947 of the housing court of Baltimore City.

The housing court is a special magistrate's court, originally created by executive order of the Governor of Maryland, with the cooperation of the city departments charged with the enforcement of building, zoning, and sanitary codes. At its most recent session, the Maryland Legislature gave the court statutory recognition and permanent status by making it part of the new municipal court system for Baltimore City. The importance of the court was emphasized by the legislature's action in providing that the judge of the housing court remain in that post for at least 1 year; judges in all other municipal courts may be rotated at any time by order of the chief judge.

On May 1, 1959, I was appointed by Governor J. Millard Tawes as magistrate of the housing court. During my first year in this post, I acquired, deservedly or not, the reputation of be-

Mr. Sweeney became an assistant attorney general for the State of Maryland on May 1, 1961. For 2 years previously he was magistrate of the housing court of Baltimore City. ing "very tough" because of a policy of levying heavy fines on slum landlords and property owners. The maximum fine the court can impose for any single violation is $\$ 100$, but each day a violation is continued can be listed as a separate violation, and, therefore, the possible fine can be much larger. (Under city laws, landlords are responsible for structural defects.) However, some landlords still treat fines as a cost of doing business.

Tenants who appear in housing court are charged with such offenses as lack of proper refuse containers and unclean or insect- or rodentinfested premises. When a health official or a police sanitarian discovers a violation, a notice of correction is issued, requiring compliance within a given period, normally 7 to 30 days. If reinspection reveals that the condition remains uncorrected, the tenant is summoned to housing court.

But fines for landlords and tenants were not sufficient to stem the spread of blight. Some radical step seemed to be needed to bring about better compliance with the law on the part of occupants of substandard homes. Many persons violated the laws regarding sanitation, health, and fire hazards not through intent, but because they had never been properly advised as to how to live in an urban setting. Many were newcomers from rural areas who were able to function quite properly in that setting, but who had failed to adjust to metropolitan living. Also, many long-time residents, because of socioeconomic problems, had never had the opportunity to learn how to achieve cleanliness and order in a substandard environment.

I felt that it would be far better for the community if these people were instructed in good living habits rather than punished with heavy 
fines which might wreak economic havoc on a family and leave the offender with no knowledge of how to prevent future violations. I discussed the plight of these persons with William Sallow, Edgar Ewing, and Albert Rosenberg, department heads of the Baltimore Urban Renewal and Housing Authority and with Wilmer Bell, director of adult education for Baltimore. These officials were equally aware of this weakness in the enforcement procedure.

As a result of these discussions, the idea for the housing clinic, as a means of instructing offenders, was born. Created in March 1960, the clinic was to operate under private auspices supervised by the author in his capacity as magistrate of the housing court. It would consist of a series of lectures, discussions, and demonstrations.

At the outset, we checked with the attorney general's office to confirm that under the existing probation powers, the housing court magistrate had sufficient authority to allow a defendant to attend a course of this nature, if the defendant agreed to do so. Authority to compel anyone to attend this clinic would not be necessary, I felt, because voluntary attendance would be a prerequisite to obtaining the complete cooperation of the student.

Tentative plans were drawn up for an 8-week course covering in detail matters fundamental to urban living. An advisory board was created consisting of members of the health department, bureau of urban renewal and housing, police department, city council, Senate and House of Delegates of the State of Maryland, and the Baltimore Bureau of Building Inspections.

A suggested curriculum was drawn up by Mr. Bell, and he recommended two eminently qualified young men who were interested in serving as moderators and instructors in the clinic. Both had experience in group counseling with the unschooled, which was especially desirable, for it was obvious that many potential candidates for the clinic were persons with little or no formal education.

The instructors, Herbert J. Stern and Richard W. Bateman, were enthusiastic about the housing clinic and agreed to accept the positions of "coordinators" for nominal salaries.
They undertook to expand the suggested curriculum and to prepare the series of eight separate programs to be given on successive weeks.

While they were thus engaged, I checked with all interested persons and agencies to make certain that the procedure which we were contemplating was legal and unobjectionable. Governor Tawes approved "enthusiastically and wholeheartedly," and J. Harold Grady, mayor of Baltimore, offered whatever assistance we might require from the city agencies.

The advisory board was convened and its members contributed many worthwhile suggestions. Officer John McAlister, sanitation bureau, Baltimore Police Department, and clerk of the housing court for 13 years, also made many practical suggestions concerning the curriculum. An unused school room, centrally located in downtown Baltimore and ideal for our purpose, was offered as a meeting place.

On April 15 a release was issued to the press and to radio and television stations in the area announcing the plans for the clinic. The release stated that we hoped to raise $\$ 1,000$ by private donations to conduct the project for a 1-year period. All of Baltimore's newspapers supported the clinic editorially, and we were able to raise the needed money in 10 days.

Beginning April 1, 1960, I began to offer the opportunity of attending the clinic to certain convicted defendants in housing court. Twenty-three defendants, approximately 25 percent of the tenants appearing before me in the court, were given the opportunity to attend the first clinic session, and all accepted.

My personal judgment was the basis for choosing the candidates. The selection was governed by such factors as the desire of the defendant to improve his living conditions, family size, educational level, financial status, and the neighborhood.

The first session on the evening of May 10, 1960 , was devoted primarily to a discussion of the laws city dwellers are compelled to observe. We also explained the methods we planned to employ in the housing clinic and expressed our purpose as the hope of creating a more wholesome atmosphere for the students and their children.

At the start, the students were uneasy, appre- 
hensive, and somewhat embarrassed at being in a group of this nature. Therefore, in welcoming them, I stressed the educational aspects of the clinic and emphasized that they had indicated their desire to become better citizens by volunteering to attend. When the coordinators took over the class at the conclusion of my opening remarks, they reiterated, and continued to emphasize throughout the 8-week course, the educational rather than the punitive nature of the clinic.

Fncouraging each student to talk about the charge which brought him to the housing court and asking him to discuss the particular problems of his neighborhood also helped to break the ice. The other students were heartened to find their difficulties were not unique.

However, the most effective step in easing the tension was stressing to these people, most of whom lived in rented homes, the legal obligations of landlords to make repairs and to keep buildings structurally safe. We also advised them of various ways to compel landlords to comply with the laws when they would not act voluntarily. We mentioned the tenant's right to legal notice before eviction and then stated what the law required of the tenant and his obligations to the landlord, his own family, and the community.

We were immensely heartened to observe as the weeks went by the increased interest and participation of our students. Their dress and grooming improved week by week, they were increasingly prompt, and unexcused absence was reduced to a bare minimum. An indication of interest was the students' request at the second session that they be permitted to bring husbands or wives to class. In the year that the course has been given, about 20 class members have brought a spouse to one or two lectures, and another 20 brought a friend or neighbor to one or more classes. One woman brought her husband to all eight sessions.

The curriculum included matters fundamental to living, particularly in a substandard urban community. An expert in a particular field lectured in understandable terms on his specialty for the first hour. The second hour was devoted to a discussion led by the coordinators on how the particular subject matter of that evening's session applied to the members of the class.

The experts were, for the most part, career city employees who gave freely of their time to assist in every phase of the project. The lecturers included an instructor in manual arts in the city schools, a captain of the fire department, a member of the Visiting Nurse Association, the clerk of the housing court, a dietitian, the director of adult education, and department heads of the bureau of urban renewal and housing authority.

The course of study appears on p. 696. This outline was followed with only minor modifications for subsequent courses. The tenants felt they knew how to make the simple household repairs demonstrated at the second session, so we eliminated this activity and devoted additional time to discussing methods for controlling insects and rodents. Also, specific problems the students raised were discussed.

Students were encouraged to put into immediate use suggestions they heard in the clinic. Each week they were urged to advise classmates of any changes or improvements in their own homes or living habits. The staff of the housing clinic was particularly encouraged by these discussions, for they were proof that the course was of practical value. When we planned the $11 / 2$-hour field trip to observe some of Baltimore's substandard areas, three students asked us to include their homes on this tour, so that they might show their classmates the improvements they had made since the clinic started.

We were impressed and touched on the evening of the last class when five or six students thanked us for our efforts in their behalf. They assured us of the good effects of the clinic and urged us to continue and expand it.

Perhaps the most gratifying reward was the discovery, by means of discreet reinspection of approximately 15 homes, that a more wholesome atmosphere prevailed. Improvement in cleanliness was the most obvious change, but there were also new curtains and newly painted walls and furniture. The most startling specific transformation was in the yard of one woman. It was knee-deep in garbage at the time she was brought into court. When she 
finished the housing clinic course her yard was as clean as it could be, and she had planted flowers in several pots.

We have also found that many graduates, emboldened by their newly acquired knowledge of a landlord's responsibilities, have compelled their landlords to make structural repairs.
It must be emphasized that the clinic has been an experiment, and we do not claim the discovery of a cure for slums. The 8-week course has been given only four times, and approximately 110 persons have attended. It is too early to evaluate it completely. The real test of the success of the housing clinic will

\section{Housing Clinic Curriculum}

\section{Orientation}

1. Explanation of law: rights and obligations of tenants and landlord.

2. Setting of tone: violators are not criminals, but are selected for potential to learn and apply ideas.

3. Explanation of content and purpose.

4. Building of relationship with and within group.

\section{Care of House and Yard}

1. Demonstration and practical exercise in simple household repairs and maintenance and rodent and insect control.

2. Building of motivation and clarification of values in caring for a home; civic responsibility.

3. Extension of group to include husbands or wives in recognition of full and mutual responsibilities of a family.

\section{Safety at Home}

1. Demonstration of fire alarm systems; discussion of fire prevention.

2. Simple first aid measures and accident prevention.

3. Practical applications in individual home setting.

\section{Family Health}

1. Group discussion under direction of resource person on physical, mental, and environmental health of the family.

(a) Practical problems, such as personal hygiene and infant care, and ways of coping with them. resources.

(b) Use of independent and community

(c) Consideration of relationship between hygiene and good health and results in better living.

\section{Economic Aspects of Family Life}

1. Overall budgeting.

2. Good food values.

3. Use of public resources.

4. Food handling, storage, preparation, and serving.

5. Consideration of responsibilities toward family and accepting public assistance (taking material help is difficult, but a hungry family must be cared for).

\section{Planning Field Trip}

1. Selection of areas of city to be visited for purpose of comparing selves with better and poorer sections and public housing areas.

2. Reconsideration of original offenses and correcting them.

3. Comparison of advantages of private and public ownership.

\section{Field Trip}

1. Visits to Tyson Street, Johannsen Street, Walbrook, Gwynns Falls Parkway, Newington Avenue, and Worsley Street areas, representing different types of residential neighborhoods.

2. Discussion en route of accomplishments, handicaps, and goals.

3. Emphasis on possibilities in use of personal initiative and resources.

Community Resources: Recapitulation and Evaluation

1. Self and family, neighborhood, broader community.

2. Reaffirmation by group of values of learning and participation in group.

3. Closing talk and presentation of "diplomas." 
come when full reinspections are made a year or more after the defendants have completed the course. If the results at that time are favorable, the difficult next step will be to expand the course facilities on a scale that will reach thousands rather than hundreds of slum dwellers.

In May 1961, the bureau of urban renewal and housing authority took over the housing clinic, relieving the magistrate of the housing court of the responsibility for operating it. The bureau now supplies the staff and funds and is continuing the clinic just as it has been conducted in the past. The magistrate continues to refer people to the course.

For the future two suggestions for expanding

\section{Ediucation Note}

Research in Medical Care. The program of graduate training in research on the organization and financing of personal health services is in its second year at the University of Michigan.

Graduate research assistantships are available to a limited number of graduate students pursuing advanced degrees in public health, social work, economics, sociology, and other social sciences as a part of the research program of the university's bureau of public health economics.

Academic appointments as research assistant are made annually on a half-time basis with a beginning stipend of $\$ 2,150$ for the academic year. They are renewable, pending review of the student's performance and academic standing.

Predoctoral fellowships are available to assist students with their doctoral dissertations. Research assistants who have participated in the clinic, which seem to have considerable merit, are being considered. One is to offer it as a free course in the public night schools in depressed areas and encourage attendance through such media as neighborhood improvement associations, police department, sanitation officers, churches, and newspapers.

The second idea is to give police and building inspectors the right to issue admission slips to the clinic instead of a summons to the housing court when they believe it would help the violator and he agrees to attend.

The effects of the clinic to date have been so encouraging that we feel we can begin to hope that it may become a new weapon in the war against slums.

the research training program, as well as other predoctoral students who are planning dissertations on topics relevant to medical care, are eligible.

A program leading to the Ph.D. degree in public health economics is also offered in the bureau. It is intended primarily for those interested in a research and teaching career in medical care.

Additional information may be obtained from Dr. S. J. Axelrod, Director, Bureau of Public Health Economics, School of Public Health, University of Michigan, Ann Arbor.

Biomedical Engineering. A program leading to a doctoral degree in biomedical engineering will be initiated at Johns Hopkins University, Baltimore, in the fall of 1961. It will combine, for the first time, advanced training in engineering subjects particularly pertinent to research in biological systems with systematic study of the application of principles of physical and engineering sciences to biological systems. The University of Pennsylvania and the University of Rochester are cooperating with Johns Hopkins in establishing similar programs. 


\section{Progiram Notes}

The Public Health Service awarded special citations to 20 U.S. steamship lines and 12 railroads in $\mathbf{1 9 6 0}$ for maintaining high standards in sanitation. Fach of these companies operates six or more conveyances. Letters of commendation were awarded to 24 smaller carrier companies. Ships and railroads are scored on more than 100 items in the PHS surveys.

« "

An institute on nutrition for the chronically ill and the aged will be held August 28-September 1, 1961, at the University of North Carolina in Chapel Hill, N.C. The program of speeches and group discussions is sponsored by the North Carolina State Board of Health, the Public Health Service, and the University of North Carolina. Information about the institute is available from Rebecca A. Broach, School of Public Health, University of North Carolina.

\section{《 $)$}

The citizens of St. Joseph, Mo., passed a $\$ 5,955,000$ bond issue for construction of sewage treatment facilities, registering a major triumph for the Federal-State program to clean up the Missouri River.

\section{« "}

Pamphlets, films, and exhibits on ways housekeeping and child care tasks can be adapted to the limitations of the physically handicapped homemaker have been announced by the School of Home Economics, University of Connecticut, Storrs, Conn. Information about these materials is available from the school.

\section{《)}

The medical and osteopathic associations in California voted in May 1961 for a merger of the two professions in that State. Under the merger, the osteopathic schools and hospitals would be in the same categories as conventional medical schools and hospitals. All trainees would receive the one M.D. degree.

Dr. Warren L. Bostick, president of the California Medical Associa- tion, said of the merger: "Unification is intended to remove any distinction among the individuals practicing medicine and surgery that is not related to skill and ability, to make available to the public efficient and adequate hospital facilities, and to improve the educational facilities available for the practice of medicine and surgery."

Later in the same month, the Philadelphia County Medical Society recommended that its members be "permitted to cooperate fully with the members of the Philadelphia County Osteopathic Society without fear of censorship." They also recommended that qualified osteopaths be admitted to the staff and facilities of all Philadelphia hospitals that are directed by doctors of medicine.

$$
\text { () }
$$

A conference on the development of safe medicine chests and safety cabinets was held by representatives of manufacturers and public health on March 8, 1961, in Washington, I.C. A draft of standards for medicine chests will soon be considered for acceptance by the entire industry. At least three companies are producing chests designed after a model developed by the Public Health Service. Seals to be placed on chests meeting approved specifications and on "child-safe" cabinets were displayed at the meeting.

$$
\text { 《) }
$$

H. J. Anslinger, U.S. Commissioner of Narcotics, reports that the number of known new narcotic addicts in 1960 was 7,479 , which is 1,858 fewer than the number for $\mathbf{1 9 5 6}$. The percentage of addicts under 21 years of age dropped from 12 in 1956 to 3.9 in 1960 . Of all the $\mathrm{Na}$ tion's addicts, 46 percent are in New York, 16 percent in California.

Anslinger advocates the building of community facilities, similar to the Federal hospitals at Lexington, Ky., and Fort Worth, Tex., for treatment and rehabilitation of addicts. A new hospital of this kind is under construction in New Jersey.
All 1962 cars will have attachments for front-seat belts. The automobile industry's announcement followed a conference between industry representatives and State Senator Edward Speno, chairman of the New York State Joint Legislative Committee on Motor Vehicles and Traffic Safety.

Legislation on seat belts had been introduced into 10 State legislatures by March 1961. The legislation ranged from urging automobile manufacturers to "consider suitable attachments" to requirement of seat belts on all new cars after a certain date.

$$
\text { < }>
$$

The first students to complete a training course for prospective aides in homes for the aged at the Hayward Adult and Technical School, Hayward, Calif., were graduated in May 1960.

The methodology, course content, and materials used in the program are described in a pamphlet published by the California State Department of Social Welfare, 722 Capitol Avenue, Sacramento 14, Calif.

$$
\text { 《) }
$$

A life-size manikin with a "breathing" apparatus, fleshlike plastic covering and the facial expression of a man in a state of shock from suffocation is being used to train students in the technique of mouth-to-mouth artificial respiration and other methods of resuscitation. Plastic valves prevent the dummy's lung from inflating unless the head is positioned properly by the student.

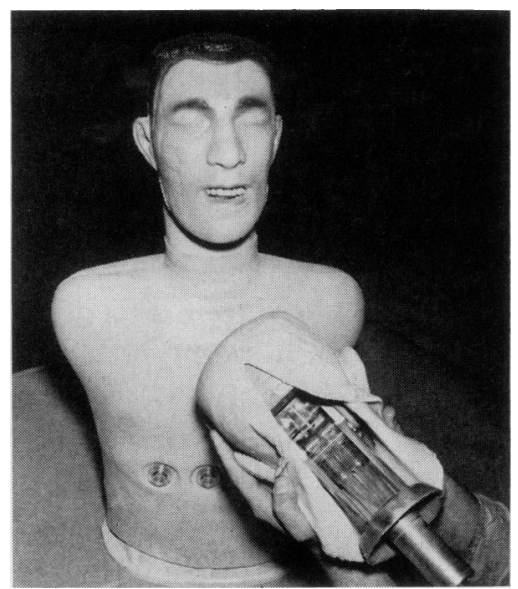

